José Florencio F. Lapeña, Jr., MA, MD

Department of Otorhinolaryngology College of Medicine, University of the Philippines Manila, Philippines

Department of Otorhinolaryngology Head and Neck Surgery

East Avenue Medical Center, Diliman

Quezon City, Philippines
Correspondence: Prof. Dr. José Florencio F. Lapeña, Jr.

Department of Otorhinolaryngology

Ward 10, Philippine General Hospital

Taft Avenue, Ermita, Manila 1000

Philippines

Phone: (632) 5548467

Telefax: (632) 5244455

Email: lapenajf@upm.edu.ph

Reprints will not be available from the author.

The author declared that this represents original material that is not being considered for publication or has not been published or accepted for publication elsewhere, in full or in part, in print or electronic media; that the manuscript has been read and approved by the author, that the requirements for authorship have been met by the author, and that the author believes that the manuscript represents honest work.

\section{Impact, Not Just Impact Factor: Responding to the Manila Declaration on the Availability and Use of Health Research Information}

The journal impact factor is defined as "the average number of times (citable) articles from the journal published in the past two years have been cited in the JCR (journal citation report) year."1 An impact factor of 1.5 means that on average, articles published 1-2 years ago have been cited one and a half times in journals included in the Web of Science. The impact factor has been used, misused and abused to rank journals within a discipline (and by inference, rank authors who are published in these journals), to evaluate the scholarly worth of a journal (and by extension, the worth of articles published in it), to decide institutional journal subscriptions, and to guide authors in choosing where to aim to submit articles to. But as has been eloquently pointed out by Amit Joshi the impact factor of a journal is not the same as its impact, or the impact of individual journal articles: A high impact factor journal may have zero impact in a remote Pacific island, just as a low impact (or no impact factor journal) may have very high impact in the country where it is read. More importantly, an article may achieve awesome impact, even if it is published in a low (or no) impact factor journal.

"To achieve real impact, and not just impact factor," the "Manila Declaration on the Availability and Use of Health Research Information in and for Low- and Middle-income Countries in the Asia Pacific Region" was launched at the 2015 Convention of the Asia Pacific Association of Medical Journal Editors (APAME 2015) held in Manila from 24 to 26 August 2015 in conjunction with the COHRED Global Forum on Research and Innovation for Health (FORUM 2015). It is concurrently published by Journals linked to APAME and listed in the Index Medicus of the South East Asia Region (IMSEAR) and the Western Pacific Region Index Medicus (WPRIM), and is published as a Special Announcement in this issue. ${ }^{3}$ It is also available online

at http://www.wpro.who.int/entity/apame/publications/en/

at http://www.hifa2015.org/wp-content/uploads/Manila_Declaration_2015_FINAL_August_242.pdf

and at http://www.equator-network.org/2015/08/28/the-manila-declaration/

The APAME 2015 convention in Manila was a meaningful and a memorable experience for the 500 editors, reviewers, authors, researchers, clinicians, scientists, students, librarians and publishers who joined us from all over the Philippines and around the world. Our participation in the New Leaders for Health Pre-Forum at the Philippine International Convention Center on 
August 22, our General Assembly and Joint Meeting with the Western Pacific Region Index Medicus and Index Medicus of the South East Asia Regions at the WHO Western Pacific Region Office on August 24, the Conjoint Sessions with the COHRED Global Forum on Research and Innovation for Health at the PICC from August 24-27 (broadcast on CNN Philippines), the APAME 2015 Convention at the Sofitel Philippine Plaza Hotel on August 25-26 (culminating in a HIFA Tweetchat), and $8^{\text {th }}$ National Medical Writing Workshop and $1^{\text {st }}$ Writeshop for Young Researchers at the Sofitel Philippine Plaza Hotel from August 27-28, comprised scientific sessions, workshops, discussions, special events and socials that were exemplary and inspiring.

Through the Manila Declaration launched at the APAME 2015, we committed "ourselves and our journals to publishing innovative and solution-focused research in all healthcare and related fields ... particularly health research applicable to low- and middleincome countries;" and committed "ourselves and our publishers to disseminating scientific, healthcare and medical knowledge fairly and impartially by developing and using ... indices ... databases ... and open data systems." ${ }^{3}$

Thus the response of the Philipp J Otolaryngol Head Neck Surg "to explore new paradigms, trends and innovations, especially with regard the social media... and "to consider the transition to a full open access model and adopting Creative Commons licenses." ${ }^{4}$ With this issue, we begin that transition, by aligning our journal with the requirements for indexing in the Directory of Open Access Journals (DOAJ), "an online directory that indexes and provides access to high quality, open access, peer-reviewed journals." ${ }^{\prime 5}$ An important part of this transition involves replacing the copyright transfer the Philippine Society of Otolaryngology Head and Neck Surgery requires of all authors published in our journal, with a Creative Commons Attribution-NonCommercial-NoDerivatives 4.0 International (CC BYNC-ND 4.0) or related license. ${ }^{6}$

We are also activating our Facebook, Twitter, and Linkedln pages, and encourage published authors, reviewers, editors and readers to "like," "tweet," and comment on our published material and the discussions, blogs and microblogs that will arise from these. To this end, we will initiate the practice of posting "laymanized abstracts" of published scientific material on our social media sites, by requesting authors of articles accepted for publication to submit such abstracts.
Meanwhile, we urgently need to improve our competencies in research, medical writing, and peer review - and this applies to young residents and senior consultants alike. While the quantity of manuscripts submitted to the journal has increased exponentially, the quality of these manuscripts leave much to be desired, as evinced by our tedious and thankless review and editing process. It is ironic that we are invited to speak on and conduct post-graduate courses and workshops in research, medical writing, peer review and editing by many other societies, colleges, academies, institutions, organizations and ministries around the country and abroad, but hardly within our very own Philippine Society of Otolaryngology Head and Neck Surgery. Be that as it may, our Fellows, Diplomates and Residents need regular medical writing and review workshops in order to improve the quality and impact of our journal articles, and consequently improve the impact of our journal. To this end, we all need to leave our comfort zones and welcome change.

Pace Heraclitus, "no man steps in the same river twice, for it's not the same river and he's not the same man," because "Пavta Pعı (Panta Rei)_All is Change."7 These transitions will not come easily, nor will they happen overnight. But they are imperative if we are to uphold our commitment "to achieve real impact, and not just impact factor, as we advance free and open access to health information and publication that improves global health-related quality of life."

\section{REFERENCES}

1. Web of Science, Thompson Reuters help page. Journal Citation Reports: Journal Impact Factor. [Cited 12 November 2015] Available at http://admin-apps.webofknowledge.com/JCR/help/h_ impfact.htm

2. Joshi A. Impact versus Impact Factor. Lecture delivered at the Asia Pacific Association of Medical Journal Editors 2015 Convention, 26 August 2015. [Cited 12 November 2015] Available at at https://mdpie.com/all-proceedings/500-apame-proceedings/apame-20150824-convention/ apame-2015-convention-session-e/2128-impact-vs-impact-factor-among-apame-journals

3. Asia Pacific Association of Medical Journal Editors. "Manila Declaration on the Availability and Use of Health Research Information in and for Low- and Middle-income Countries in the Asia Pacific Region." (Special Announcement) Philipp J Otolaryngol Head Neck Surg. 2015 Jul - Dec; 30(2):6-7. Also available at http://www.wpro.who.int/entity/apame/publications/en/

4. Lapeña JF. "Advancing Access to Health Information and Publication: Shifting Paradigms, Trends and Innovations." Philipp J Otolaryngol Head Neck Surg. 2015 Jan - Jun; 30(1):4-5.

5. Directory of Open Access Journals. [Cited 7 November 2015] Available at https://doaj.org

6. Creative Commons Attribution-NonCommercial-NoDerivatives 4.0 International (CC BY-NC-ND 4.0) license. [Cited 7 November 2015] Available at http://creativecommons.org/licenses/by-nc$\mathrm{nd} / 4.0 /$

7. Heraclitus of Ephesus. [Cited 7 November 2015] Available from http://www.optionality.net/ heraclitus/ 